\title{
Phytic acid content and in-vitro digestibility of several cereal and legume types treated with different processes
}

\section{Müberra Bektaş ${ }^{1}$, Müge Hendek Ertop ${ }^{2}$}

\author{
1 - Gümüşhane University, Gümüşhane, Turkey \\ 2 - Kastamonu University, Kastamonu, Turkey
}

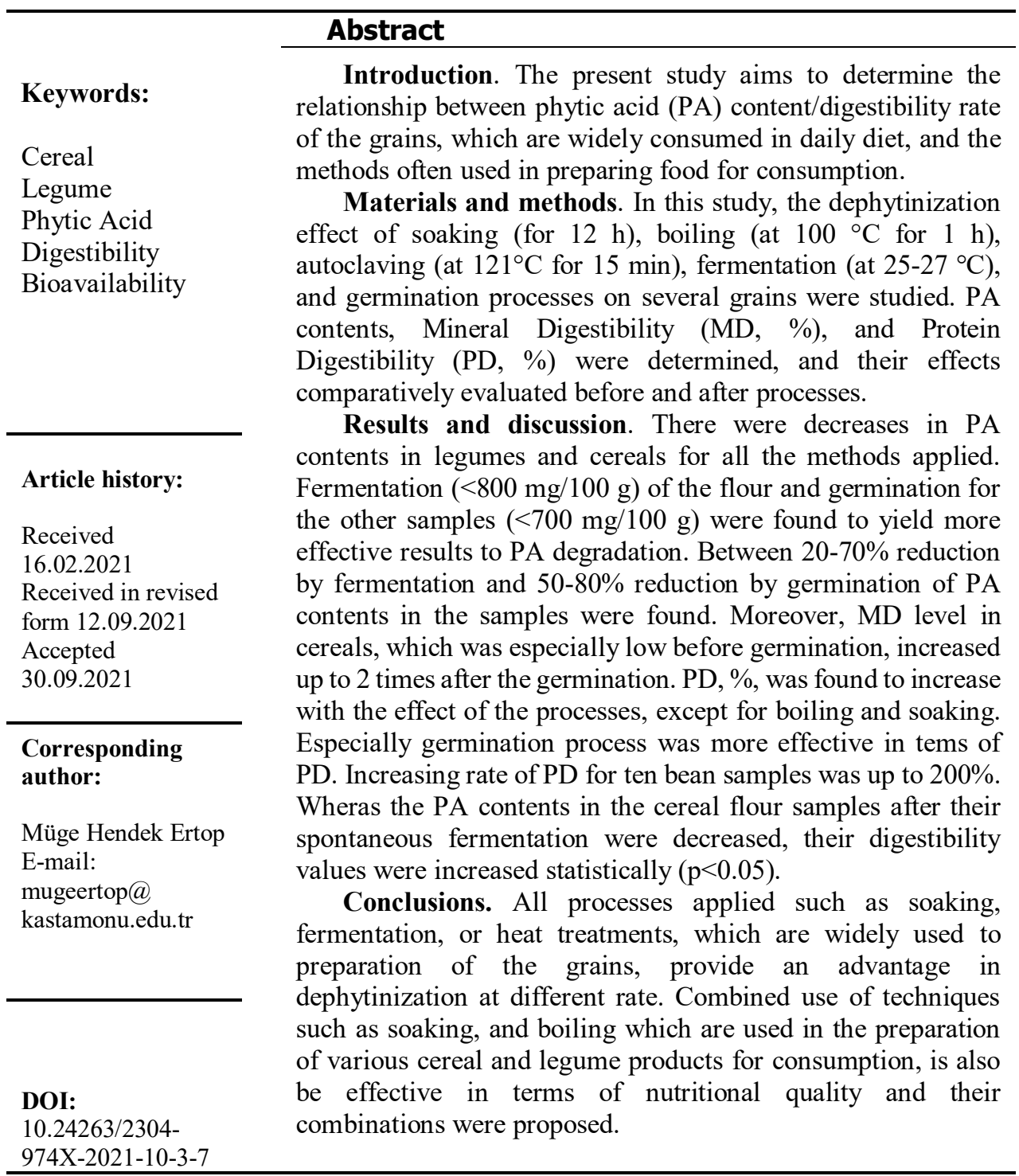




\section{Introduction}

The cereals and legumes have a poor nutritional value in comparison with the animal source foods, due to their amino acid compositions and lack of some essential micronutrients. Additionally, most of the cereals and legumes contain high amount of phytic acid (PA), which is considered as an antinutrient compound because of its ability to form strong chelates with metal cations, especially with $\mathrm{Ca}^{+2}, \mathrm{Zn}^{+2}$, and $\mathrm{Fe}^{+2}$, to form phylate and decrease bioavailability of these important microelements in the human intenstine (Gibson et al., 2010; Özkaya et al., 2018; Perera et al., 2018). Therefore, diets that are rich in cereals and legumes having high phytate content may lead to micronutrients deficiency (Ma et al., 2013). In cereal grains such as wheat and rice, $\mathrm{PA}\left(\mathrm{C}_{6} \mathrm{H}_{18} \mathrm{O}_{24} \mathrm{P}_{6}\right.$, inositol hexaphosphates-IP6) is found in bran fraction such as aleurone layer and pericarp, and in corn it is found in endosperm (Gupta et al., 2015). PA is the primary storage form of phosphorus, comprising $1-5 \%$ by weight in cereals, nuts and legumes (Vats and Banerjee, 2004). PA exhibits high binding capacity with positively charged proteins via electrostatic interactions and affects their activity (Pakfetrat et al., 2018; Wang and Guo, 2021).

Increasing micronutrient intake and bioavailability in food through food processing is a sustainable method to prevent micronutrient malnutrition (Ertop and Bektaş, 2018). The pretreatment and processing techniques widely used in preparing the foods might yield a reduction in antinutrient compounds. Soaking, dehulling, cooking and fermentation are important traditional methods used to reduce antinutrients. Furthermore, germination and fermentation enhance the nutritional value of cereals and legumes due to significant changes in chemical composition and elimination of antinutritional factors (Abdelrahaman et al., 2005). Several studies were conducted on certain grains and seeds which examined their antinutrients and nutritional properties under different processes and conditions (Özkaya et al., 2017a; Özkaya et al., 2017b; Deng et al., 2015; Yagoubet al., 2008; Rehman and Salariya, 2005). However, no study comparatively analyzing industrial/domestic common methods for treatment of grains having high consumption rates was found. The present study aims to fill this gap about the relationship between phytic acid content/digestibility rate of grains, which are widely consumed, and the methods often used in preparation of food for consumption.

\section{Materials and methods}

\section{Materials}

The wheat sample named as "Ekiz wheat" (Triticum aestivum) was supplied from the crops harvested in July 2017 at Devrekani, Kastamonu, Turkey. The flour was milled (milling yield $70 \%$ ) in a milling factory (Üçbaşak Milling, Devrekani, Kastamonu). The hulled rice (paddy) and rice sample (milling yield 68\%) were supplied from a local rice producer. For preparing the rice flour, the dried rice grains were milled using a laboratory mill (EQM-402 Mixer Mill, Spain). The barley sample named "Aydan Hanım", local oat sample, and rye sample named "Black rye" were supplied from the crops harvested in 2017 from Gövdecili village of Yozgat, Turkey, and the samples were milled in traditional stone mills of a local company. Before the milling process (stone mill), the grains (barley, oat and rye) were hydrated by adding $200 \mathrm{~g}$ water per $10 \mathrm{~kg}$ of the kernel to make the seed coats less brittle and to prevent kernel breakage (Bottega et al., 2009). Dry bean, chickpea, and green lentil samples were obtained from a commercial firm in Kastamonu, Turkey. 


\section{Proximate analyses}

Ash, protein, and moisture contents of the samples were determined using AACC Approved Methods (AACC, 2000) and numbered as 08-01.01, 46-12.01, and 44-15.02, respectively. The nutrient or mineral contents were expressed on a dry matter basis. $\mathrm{pH}$ values of the fermented samples were measured using a digital $\mathrm{pH}$ meter (Ohaus ST3100). Phytic acid content was determined by using the colorimetric procedure of Haug and Lantzsch (1983) and content of phytic acid was calculated accordingly.

\section{Sample preparation}

Soaking. Ten grams of cereal and legume grains were weighed and soaked with $10 \mathrm{~mL}$ water and kept under the room temperature for $12 \mathrm{~h}$.

Germination. Fifty grams of cereal and legume grains were washed and then immersed in $100 \mathrm{~mL}$ of water at $20-24{ }^{\circ} \mathrm{C}$ for $8 \mathrm{~h}$. Grain samples were drained and kept for $8 \mathrm{~h}$ without water to attain a homogenous moisture distribution from crumb to crust. Then, 2 more times these processes were re-performed. The grains were placed in the dishes having $40-50 \mathrm{~mm}$ diameter, their bottom and top surface covered with cotton paper, and they were kept at $25 \pm 2$ ${ }^{\circ} \mathrm{C}$ (Pakfetrat et al., 2018). To supply the germination moisture, a certain amount of water was sprayed onto the grains every day for a total of 4-5 days of germination. The germination process was terminated when the germinated part reached the original size of the grains.

\section{Hydrothermal processes.}

Autoclaving. Ten grams of cereal and legume grains and $10 \mathrm{~mL}$ water were placed into borosilicate glasses, and the heat treatment was performed at $121{ }^{\circ} \mathrm{C}$ for $15 \mathrm{~min}$ in the autoclave.

Boiling. Ten grams of cereal and legume grains were weighed and boiled in $10 \mathrm{~mL}$ water at $100{ }^{\circ} \mathrm{C}$ for $1 \mathrm{~h}$ in a water bath.

Fermentation. The spontaneous fermentation technique (back-slopping method) was used for fermentation of wheat, oats, barley, rye, and rice flour. Ten grams of wheat flour and $10 \mathrm{~g}$ water (dough yield: 200) (Hayta and Ertop, 2018) were mixed and fermented spontaneously in 3 stages until the dough reached $\mathrm{pH}$ levels lower than 4.5 at $25-27^{\circ} \mathrm{C}$.

\section{In-vitro mineral (MD) and protein digestibility (PD) determination}

The sample $(1 \mathrm{~g})$ was incubated with $25 \mathrm{~mL}$ of pepsin solution $(0.03 \mathrm{~N} 1 \mathrm{~L} \mathrm{HCl}+2 \mathrm{~g}$ of pepsin) at $37^{\circ} \mathrm{C}$ for $3 \mathrm{~h}$. Each sample was filtered using ashless filter paper. The pellet and filter paper were burned together in the furnace at $900{ }^{\circ} \mathrm{C}$, and the ash content was calculated. The digestible mineral content was obtained together with their differences. The MD, \%, values were obtained (Hayta and Ertop, 2018) by using the following equation:

$$
M D, \%=\frac{\text { Digestible Mineral Content }}{\text { Total Mineral Content }} \times 100
$$

The in-vitro PD values determined by the method of Rizzello et al. (2014) PD, \%, values were calculated using the following equation: 


$$
\begin{gathered}
- \text { Food Technology }- \\
P D, \%=\frac{N \text { in supernatant }-N \text { in pepsin enzyme }}{N \text { in sample }} \times 100,
\end{gathered}
$$

where $\mathrm{N}$ is content of nitrogen.

\section{Statistical analysis}

The data were shown as the mean \pm standard deviation. Variance analysis (ANOVA) (IBM-SPSS 1.0.0.781) by Tukey test $(\mathrm{p}<0.05)$ was used for comparing the results between all samples. t-test was carried out before and after the procedure in order to determine the effects of application $(\mathrm{p}<0.05)$.

\section{Results and discussion}

\section{Effects of the soaking process}

There were statistically significant differences $(p<0.05)$ between the phytic acid contents of raw grains (Table 1). The highest PA content was found in wheat grain, while the lowest content was found in paddy. The contentss found in legumes (bean, chickpea, and green lentil) were similar to each other. The PA content in the grains was significantly $(p<0.05)$ decreased by the soaking process $<$ and their PA contents were very close to each other.

Phytates are concentrated in endosperm in legume seeds (Lestienne et al., 2005). The bran and husk fractions in cereals contain higher amount of PA. Therefore, during the soaking process, the water can reach phytase in the bran and husk layer of the grains more easily compared to the central endosperm layer of legume grains. The soaking process increased the $\mathrm{MD}, \%$, of the cereal and legume grains and the difference was found to be statistically significant in all the samples $(\mathrm{p}<0.05)$. Moreover, it was also found that the MD, $\%$, of the legumes before and after the soaking process was higher than that of cereals. It has been shownin several studies that soaking of the cereals and beans reduced the PA content and consequently increases the MD (Perlas and Gibson, 2002; Coulibaly et al., 2011).

The soaking process decreased the protein digestibility rate of all the cereal and legume grains, and the change was found to be statistically significant, especially for rye, paddy, chickpea, and green lentil. This might be due the protease inhibition (trypsin inhibitor), which is an antinutrient compound found in raw legumes and certain cereals. It was demonstrated that protease inhibitors reduce the proteolysis, amino acid absorption, and protein bioavailability of diet proteins by suppressing the activities of trypsin, chymotrypsin, and amylase enzymes in the small intestine (Ergün et al., 2002). Oomah et al. (2011) found that trypsin inhibitors have capability to inactivate trypsin and digestive enzymes. Accordingly, despite the hydrolysis of PA in the soaking process, it can be stated that the protease inhibitor reduces the digestion of proteins in the intestinal $\mathrm{pH}$ in-vitro medium and thus reduces the protein digestibility rate of cereals and legumes. It was found that the heating increased protein digestibility in legumes due to the inactivation of protease inhibitors and the denaturation of the proteins (Eltayeb et al., 2007).Therefore, the use of the soaking process altogether with other treatments such as germination, heating, and fermentation colud be very useful. Phytic acid contents and digestibility rates of the samples before and after soaking process are shown in Table 1. 
Table 1

Phytic acid contents (a) and digestibility rates (b and c) of the samples before and after soaking process

(a)

\begin{tabular}{|l|c|c|c|}
\hline \multirow{3}{*}{ Sample } & \multicolumn{3}{|c|}{ Content of phytic acid, mg/100 g } \\
\cline { 2 - 4 } & Before & After & $\boldsymbol{p}$ value* \\
\hline Wheat & $2471.88 \pm 0.31^{\mathrm{a}}$ & $1487.50 \pm 2.56^{\mathrm{a}}$ & 0.002 \\
\hline Barley & $2328.13 \pm 2.08^{\mathrm{b}}$ & $1356.25 \pm 0.01^{\mathrm{g}}$ & 0.000 \\
\hline Rye & $1715.63 \pm 1.10^{\mathrm{g}}$ & $1390.63 \pm 0.31^{\mathrm{e}}$ & 0.001 \\
\hline Oat & $2050.00 \pm 2.74^{\mathrm{c}}$ & $1312.50 \pm 0.62^{\mathrm{h}}$ & 0.001 \\
\hline Paddy & $1559.38 \pm 0.22^{\mathrm{h}}$ & $1428.13 \pm 0.13^{\mathrm{d}}$ & 0.001 \\
\hline Bean & $1831.25 \pm 1.59^{\mathrm{d}}$ & $1450.00 \pm 0.09^{\mathrm{c}}$ & 0.000 \\
\hline Chickpea & $1806.25 \pm 0.88^{\mathrm{e}}$ & $1478.13 \pm 0.49^{\mathrm{b}}$ & 0.001 \\
\hline Green lentil & $1790.63 \pm 0.49^{\mathrm{f}}$ & $1368.75 \pm 0.80^{\mathrm{f}}$ & 0.001 \\
\hline
\end{tabular}

(b)

\begin{tabular}{|l|c|c|c|}
\hline \multirow{3}{*}{ Sample } & \multicolumn{3}{|c|}{ Mineral digestibility, \% } \\
\cline { 2 - 4 } & Before & After & p value* \\
\hline Wheat & $45.38 \pm 4.60^{\text {abc }}$ & $71.91 \pm 1.75^{\text {bcd }}$ & 0.042 \\
\hline Barley & $40.72 \pm 0.00^{\text {bcd }}$ & $65.72 \pm 1.67^{\text {de }}$ & 0.042 \\
\hline Rye & $45.70 \pm 0.42^{\text {acc }}$ & $70.10 \pm 1.91^{\text {cd }}$ & 0.050 \\
\hline Oat & $36.24 \pm 2.01^{\text {cd }}$ & $62.49 \pm 1.78^{\mathrm{e}}$ & 0.043 \\
\hline Paddy & $30.16 \pm 1.01^{\mathrm{d}}$ & $60.61 \pm 0.45^{\mathrm{e}}$ & 0.009 \\
\hline Bean & $53.83 \pm 1.89^{\mathrm{a}}$ & $79.21 \pm 0.65^{\mathrm{ab}}$ & 0.016 \\
\hline Chickpea & $52.16 \pm 2.74^{\mathrm{ab}}$ & $84.11 \pm 0.62^{\mathrm{a}}$ & 0.012 \\
\hline Green lentil & $52.47 \pm 0.14^{\mathrm{ab}}$ & $77.32 \pm 1.33^{\mathrm{abc}}$ & 0.034 \\
\hline
\end{tabular}

(c)

\begin{tabular}{|l|c|c|c|}
\hline \multirow{3}{*}{ Sample } & \multicolumn{3}{|c|}{ Protein digestibility, \% } \\
\cline { 2 - 4 } & Before & After & $p$ value $^{*}$ \\
\hline Wheat & $50.66 \pm 3.30^{\mathrm{bc}}$ & $47.07 \pm 1.97^{\mathrm{b}}$ & 0.320 \\
\hline Barley & $36.49 \pm 0.97^{\mathrm{de}}$ & $33.38 \pm 1.57^{\mathrm{c}}$ & 0.298 \\
\hline Rye & $53.81 \pm 3.19^{\mathrm{b}}$ & $35.33 \pm 1.16^{\mathrm{c}}$ & 0.040 \\
\hline Oat & $40.54 \pm 0.10^{\mathrm{cd}}$ & $43.54 \pm 0.92^{\mathrm{b}}$ & 0.189 \\
\hline Paddy & $48.69 \pm 1.24^{\mathrm{bc}}$ & $13.93 \pm 1.40^{\mathrm{e}}$ & 0.022 \\
\hline Bean & $25.98 \pm 0.08^{\mathrm{e}}$ & $25.07 \pm 1.19^{\mathrm{d}}$ & 0.584 \\
\hline Chickpea & $77.29 \pm 2.24^{\mathrm{a}}$ & $61.00 \pm 1.10^{\mathrm{a}}$ & 0.043 \\
\hline Green lentil & $71.60 \pm 2.65^{\mathrm{a}}$ & $20.95 \pm 0.52^{\mathrm{de}}$ & 0.007 \\
\hline
\end{tabular}


Phytic acid contents (a) and digestibility rates (b and c) of the samples before and after

Table 2 germination process

(a)

\begin{tabular}{|l|c|c|c|}
\hline \multirow{2}{*}{ Sample } & \multicolumn{3}{|c|}{ Content of phytic acid, mg/100 g } \\
\cline { 2 - 4 } & Before & After & $\boldsymbol{p}$ value* \\
\hline Wheat & $2471.87 \pm 0.31^{\mathrm{a}}$ & $621.68 \pm 0.67^{\mathrm{b}}$ & 0.000 \\
\hline Barley & $2328.12 \pm 2.08^{\mathrm{b}}$ & $548.79 \pm 0.79^{\mathrm{e}}$ & 0.000 \\
\hline Rye & $1715.62 \pm 1.10^{\mathrm{g}}$ & $488.48 \pm 0.07^{\mathrm{f}}$ & 0.000 \\
\hline Oat & $2050.00 \pm 2.74^{\mathrm{c}}$ & $576.14 \pm 0.44^{\mathrm{d}}$ & 0.000 \\
\hline Paddy & $1559.37 \pm 0.22^{\mathrm{h}}$ & $698.19 \pm 0.54^{\mathrm{a}}$ & 0.000 \\
\hline Bean & $1831.25 \pm 1.59^{\mathrm{d}}$ & $463.43 \pm 0.17^{\mathrm{g}}$ & 0.000 \\
\hline Chickpea & $1806.25 \pm 0.88^{\mathrm{e}}$ & $616.56 \pm 0.65^{\mathrm{c}}$ & 0.000 \\
\hline Green lentil & $1790.63 \pm 0.49^{\mathrm{f}}$ & $441.36 \pm 0.80^{\mathrm{h}}$ & 0.000 \\
\hline
\end{tabular}

(b)

\begin{tabular}{|l|c|c|c|}
\hline \multirow{2}{*}{ Sample } & \multicolumn{3}{|c|}{ Mineral digestibility, \% } \\
\cline { 2 - 4 } & Before & After & $\boldsymbol{p}$ value \\
\hline Wheat & $45.38 \pm 4.60^{\text {abc }}$ & $79.97 \pm 1.39^{\mathrm{b}}$ & 0.026 \\
\hline Barley & $40.72 \pm 0.00^{\mathrm{bcd}}$ & $76.76 \pm 1.06^{\mathrm{bc}}$ & 0.019 \\
\hline Rye & $45.70 \pm 0.42^{\mathrm{abc}}$ & $83.67 \pm 0.77^{\mathrm{ab}}$ & 0.013 \\
\hline Oat & $36.24 \pm 2.01^{\mathrm{de}}$ & $79.83 \pm 1.33^{\mathrm{b}}$ & 0.019 \\
\hline Paddy & $30.16 \pm 1.01^{\mathrm{e}}$ & $61.29 \pm 1.58^{\mathrm{d}}$ & 0.032 \\
\hline Bean & $53.83 \pm 1.89^{\mathrm{a}}$ & $86.03 \pm 1.06^{\mathrm{a}}$ & 0.021 \\
\hline Chickpea & $52.16 \pm 2.74^{\mathrm{ab}}$ & $83.18 \pm 0.98^{\mathrm{ab}}$ & 0.020 \\
\hline Green lentil & $52.47 \pm 0.14^{\mathrm{ab}}$ & $73.60 \pm 0.90^{\mathrm{c}}$ & 0.027 \\
\hline
\end{tabular}

(c)

\begin{tabular}{|l|c|c|c|}
\hline \multirow{2}{*}{ Sample } & \multicolumn{3}{|c|}{ Protein digestibility, \% } \\
\cline { 2 - 4 } & Before & After & $\boldsymbol{p}$ value* \\
\hline Wheat & $50.66 \pm 3.30^{\mathrm{bc}}$ & $68.54 \pm 1.00^{\mathrm{e}}$ & 0.036 \\
\hline Barley & $36.49 \pm 0.97^{\mathrm{de}}$ & $74.08 \pm 1.17^{\mathrm{d}}$ & 0.020 \\
\hline Rye & $53.81 \pm 3.19^{\mathrm{b}}$ & $85.82 \pm 0.88^{\mathrm{a}}$ & 0.017 \\
\hline Oat & $40.54 \pm 0.10^{\mathrm{cd}}$ & $79.42 \pm 1.00^{\mathrm{bc}}$ & 0.016 \\
\hline Paddy & $48.69 \pm 1.24^{\mathrm{bc}}$ & $64.16 \pm 1.01^{\mathrm{e}}$ & 0.042 \\
\hline Bean & $25.98 \pm 0.08^{\mathrm{e}}$ & $79.97 \pm 1.21^{\mathrm{b}}$ & 0.014 \\
\hline Chickpea & $77.29 \pm 2.24^{\mathrm{a}}$ & $78.07 \pm 0.01^{\mathrm{bcd}}$ & 0.008 \\
\hline Green lentil & $71.60 \pm 2.65^{\mathrm{a}}$ & $74.16 \pm 0.77^{\mathrm{cd}}$ & 0.186 \\
\hline
\end{tabular}

* $(P<0.05)$ means that the values statistically different in the same line

**Different letters indicate significant differences $(P<0.05)$ in the same column 


\section{Effects of germination process}

A significant decrease $(\mathrm{p}<0.05)$ was obtained in the PA contents in all grains and legumes after the germination process (Table 2). In several studies (Eltayeb et al., 2007; Greiner and Konietzny, 2006; Marshall et al., 2011) it was also reported that germination is a very effective method for reducing contents of phytate acid and other antinutrient factors in grains. During the germination process, activation of the phytase enzyme accelerates, so its ability to break phytates down increases (Fayyaz et al., 2018). Moreover, it was reported that the pre-soaking process before germination caused a significant reduction from $55 \%$ to $76 \%$ of PA content in the grains (Masud et al., 2007). Therefore, germination is the most effective method to decrease the content of PA (Figure1).

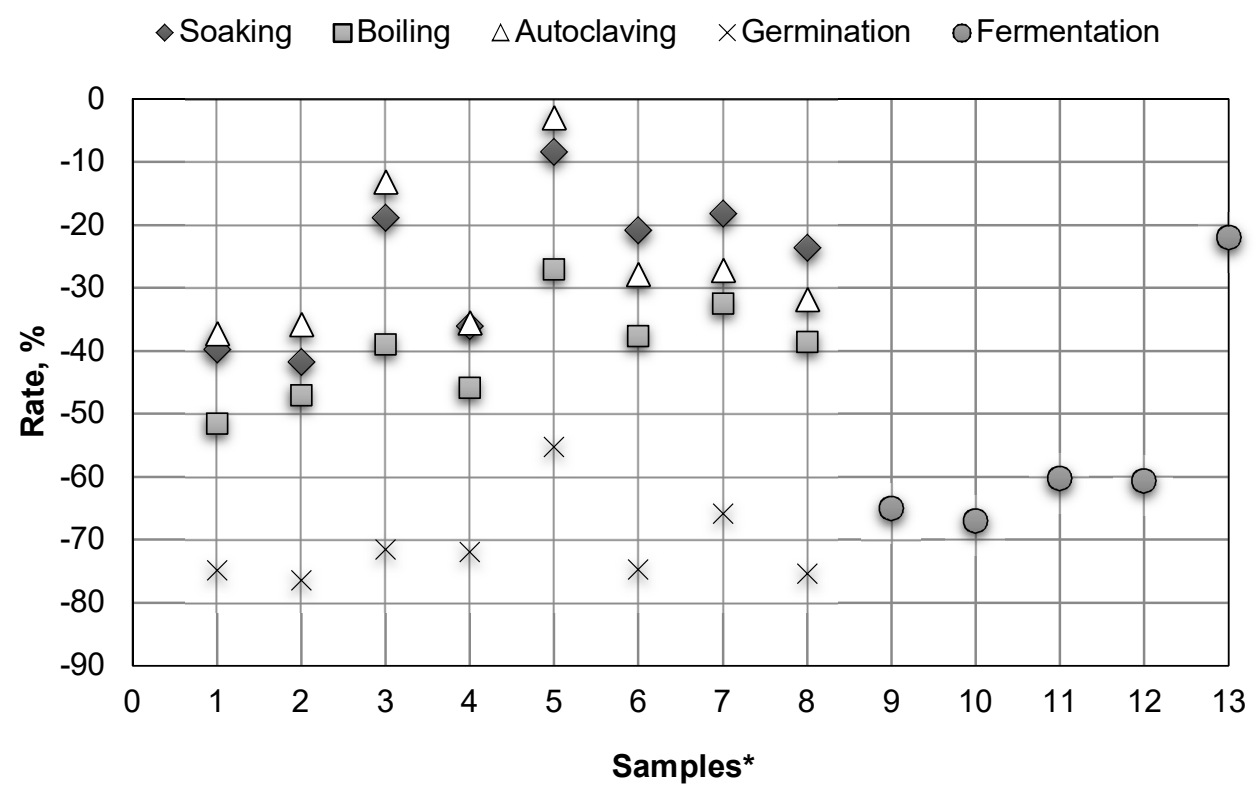

Figure 1. Effect of the processes on the rate, $\%$, of change of the phytic acid content

${ }^{*}$ Number of the samples;

1 - Wheat, 2 - Barley, 3 - Rye, 4 - Oat, 5 - Paddy, 6 - Bean, 7 - Chickpea; 8 - Green lentil, 9 - Wheat flour, 10 - Barley flour, 11 - Rye flour, 12 - Oat flour, 13 - Rice flour

Application of all processing methods increased the MD level in all samples. Germination was the most effective method among them (Figure 2). The germination process significantly increased the MD rates for both grain and legume samples $(\mathrm{p}<0.05)$ (Table 2). The MD level in cereals, which was especially low before germination, increased up to 2 times after the germination. The most affected sample was the paddy. The highest increase among the legumes was found for chickpeas. Masud et al. (2007) showed that germination is a highly effective method thanks to the reduction of PA content by up to $40 \%$. Although the non-germinated grains have a low endogenous enzyme activity (Greiner and Konietzny, 2006), the endogenous 
phytase activity degrading the phytate increased during the germination of grains. Thus, PA affecting the bioavailability of major minerals such as $\mathrm{Ca}$ and trace ones such as $\mathrm{Fe}, \mathrm{Cu}, \mathrm{Zn}$ and Mn and binding them was degraded (Ertop and Bektaş, 2018). It was found that the total ash content in such legumes as mug beans, pea, and lentil increased after the germination process (Fayyaz et al., 2018; El-Adawy et al., 2003). Therefore, the increase of MD might be due to the increased ash (total mineral) content of the sprouted grain.

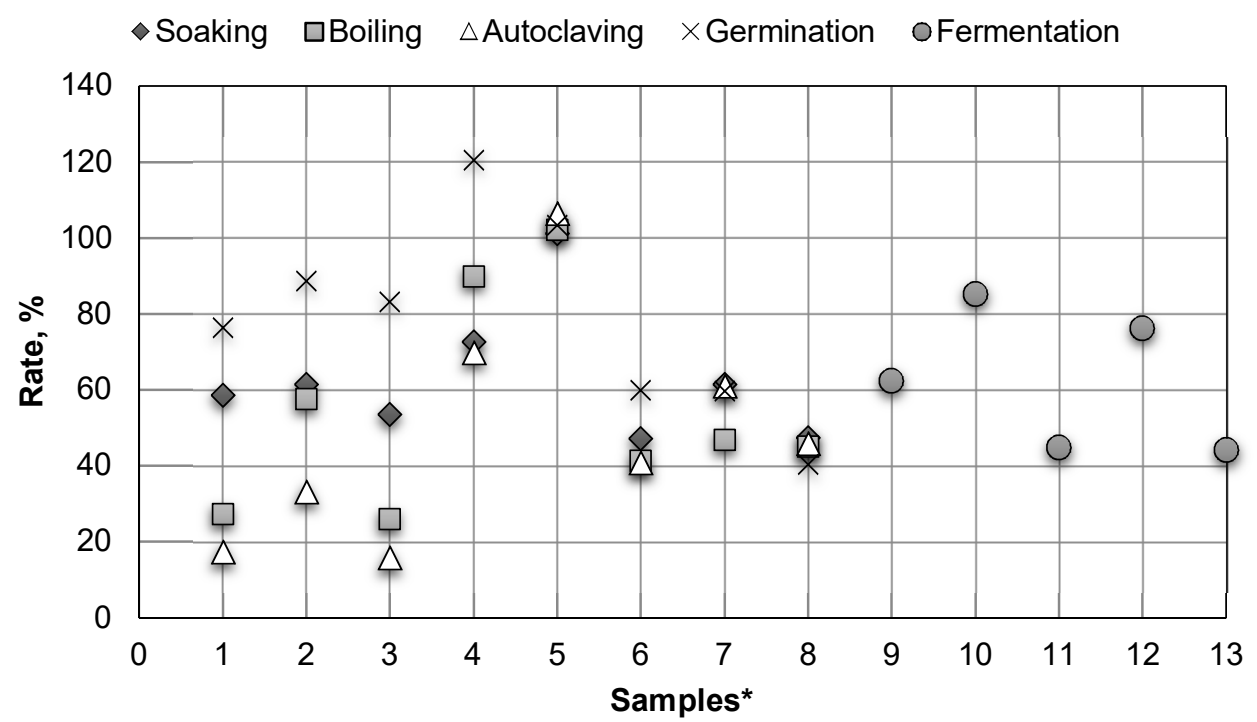

Figure 2. Effect of the processes on the rate, \%, of change in the MD:

${ }^{*}$ Number of the samples;

1 - Wheat, 2 - Barley, 3 - Rye, 4 - Oat, 5 - Paddy, 6 - Bean, 7 - Chickpea; 8 - Green lentil, 9 - Wheat flour, 10 - Barley flour, 11 - Rye flour, 12 - Oat flour, 13 - Rice flour

The germination method was the most effective method in increasing the PD value of cereals, especially the barley, rye, and oats (Figure 3). The germination process increased $(p<0.05)$ the PD, \%, for all grain and legume samples except for green lentils (Table 2). Legumes are valuable plant-based protein sources in the daily diet. However, besides the level of proteins, their digestibility rate is also important. It was determined that the PD, $\%$, of the bean, which was rather low, $25.98 \%$, initially, increased significantly to $79.97 \%$ after the germination (Table 2). An approximately 207\% increase was served for the bean (Figure 3). The barley exhibited a result similar to the bean. The PA in grains is in the form of complexes with proteins and several metal cations. The inhibition of PA, which depends on the phytase activity during the germination, resulted in an increase in the PD. In a study carried out by Ghavidel and Prakash (2007), germination significantly improved the in-vitro bioavailability of $\mathrm{Fe}$ and $\mathrm{Ca}$ minerals, protein, and thiamine, as well as in-vitro digestibility of starch and proteins in several legumes. The germination process increased the amount of protein and particularly the amount of amino acids such as lysine and tryptophan in the Mung bean (Adil Shah et al., 2011) and oats (Peterson, 1998; Skoglund et al., 2008). Thus, the nutritional value was increased. Sharif et al. (2013) reported that, together with the increase of the protease 
enzyme activity because of the germination process, the protein quality of the grain increased, lysine content and protein bioavailability enhanced, and the minerals became more useful by chelating with proteins. Increase of PD in germinated grains was due to the removal of certain antinutrients such as protease inhibitor (trypsin inhibitor) and PA (Khalil and Mansour, 1995).

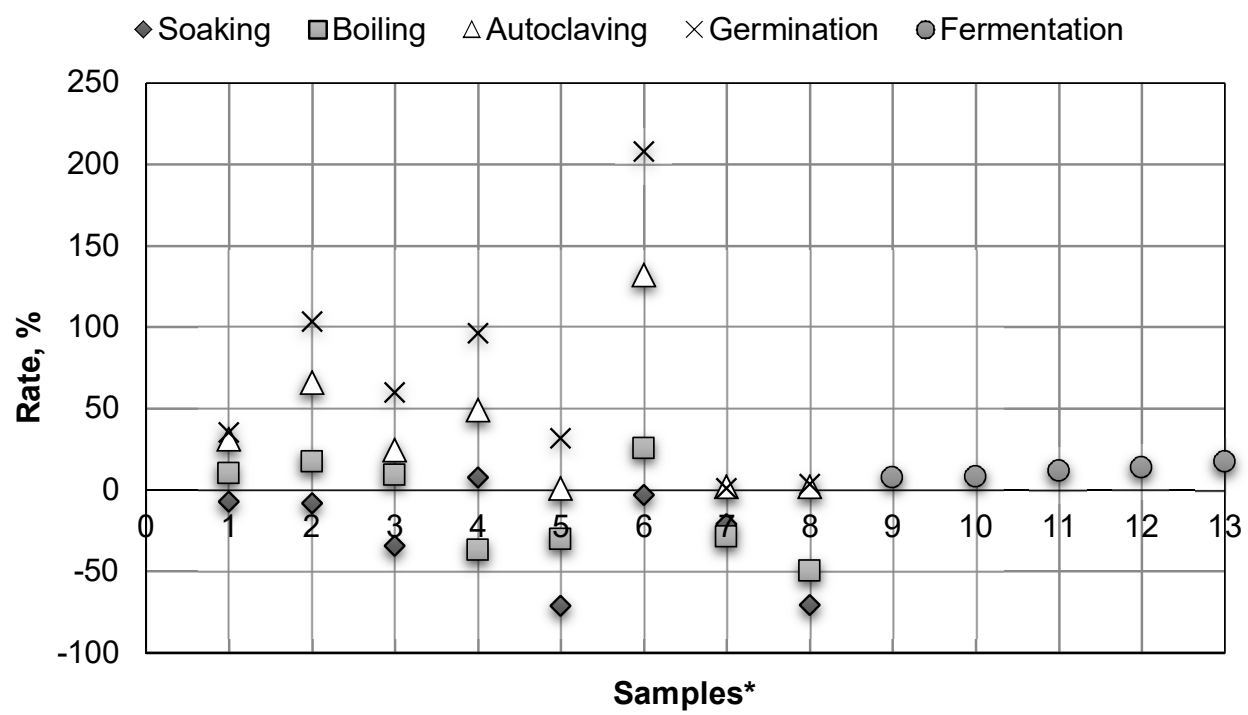

Figure 3. Effect of the processes on the rate, $\%$, of change in the PD

${ }^{*}$ Number of the samples;

1 - Wheat, 2 - Barley, 3 - Rye, 4 - Oat, 5 - Paddy, 6 - Bean,

7 - Chickpea; 8 - Green lentil, 9 - Wheat flour, 10 - Barley flour,

11 - Rye flour, 12 - Oat flour, 13 - Rice flour

\section{Effects of hydrothermal processes}

\section{Autoclaving}

The autoclaving process yielded a significant $(p<0.05)$ decrease in the PA content in all grains, as seen in Table 3 . The wheat sample had the highest phytic acid content before and after the treatment. After autoclaving, the highest PA content among the grains was in wheat, whereas the lowest level was in the rye sample. Among the legume samples, PA was at the same level in beans and chickpeas and higher than in the green lentil $(\mathrm{p}<0.05)$.

An increase in MD, \%, in both legumes and grains was achieved by autoclaving and the change was statistically significant $(\mathrm{p}<0.05)$ in all samples, except for rye. However, the digestibility of legumes was higher than cereals before autoclaving and this did not change after the treatment. Post-treatment digestibility rates of cereals were determined to be in the range from 52.23 to $62.19 \%$ and those of legumes was in the range from 75.50 to $83.95 \%$. 
Table 3

Phytic acid contents (a) and digestibility rates (b and c) of the samples before and after autoclaving process

(a)

\begin{tabular}{|l|c|c|c|}
\hline \multirow{2}{*}{ Sample } & \multicolumn{3}{|c|}{ Content fo phytic acid, mg/100 g } \\
\cline { 2 - 4 } & Before & After & $\boldsymbol{p}$ value* $^{*}$ \\
\hline Wheat & $2471.87 \pm 0.31^{\mathrm{a}}$ & $1553.13 \pm 2.43^{\mathrm{a}}$ & 0.002 \\
\hline Barley & $2328.12 \pm 2.08^{\mathrm{b}}$ & $1493.75 \pm 0.62^{\mathrm{c}}$ & 0.000 \\
\hline Rye & $1715.62 \pm 1.10^{\mathrm{g}}$ & $1490.63 \pm 1.81^{\mathrm{c}}$ & 0.005 \\
\hline Oat & $2050.00 \pm 2.74^{\mathrm{c}}$ & $1321.88 \pm 0.40^{\mathrm{d}}$ & 0.000 \\
\hline Paddy & $1559.37 \pm 0.22^{\mathrm{h}}$ & $1512.5 \pm 0.02^{\mathrm{b}}$ & 0.000 \\
\hline Bean & $1831.25 \pm 1.59^{\mathrm{d}}$ & $1321.88 \pm 0.66^{\mathrm{d}}$ & 0.001 \\
\hline Chickpea & $1806.25 \pm 0.88^{\mathrm{e}}$ & $1315.63 \pm 0.13^{\mathrm{d}}$ & 0.000 \\
\hline Green lentil & $1790.63 \pm 0.49^{\mathrm{f}}$ & $1221.88 \pm 1.19^{\mathrm{e}}$ & 0.001 \\
\hline
\end{tabular}

(b)

\begin{tabular}{|l|c|c|c|}
\hline \multirow{2}{*}{ Sample } & \multicolumn{3}{|c|}{ Mineral digestibility, \% } \\
\cline { 2 - 4 } & \multicolumn{1}{|c|}{ Before } & After & $\boldsymbol{p}$ value* \\
\hline Wheat & $45.38 \pm 4.60^{\mathrm{abc}}$ & $53.23 \pm 0.42^{\mathrm{d}}$ & 0.034 \\
\hline Barley & $40.72 \pm 0.00^{\mathrm{bcd}}$ & $54.15 \pm 1.01^{\mathrm{d}}$ & 0.048 \\
\hline Rye & $45.70 \pm 0.42^{\mathrm{abc}}$ & $52.86 \pm 1.08^{\mathrm{d}}$ & 0.095 \\
\hline Oat & $36.24 \pm 2.01^{\mathrm{cd}}$ & $61.52 \pm 0.96^{\mathrm{c}}$ & 0.024 \\
\hline Paddy & $30.16 \pm 1.01^{\mathrm{d}}$ & $62.19 \pm 0.31^{\mathrm{c}}$ & 0.006 \\
\hline Bean & $53.83 \pm 1.89^{\mathrm{a}}$ & $75.75 \pm 1.55^{\mathrm{b}}$ & 0.045 \\
\hline Chickpea & $52.16 \pm 2.74^{\mathrm{ab}}$ & $83.95 \pm 0.83^{\mathrm{a}}$ & 0.017 \\
\hline Green lentil & $52.47 \pm 0.14^{\mathrm{ab}}$ & $76.49 \pm 0.98^{\mathrm{b}}$ & 0.026 \\
\hline
\end{tabular}

(c)

\begin{tabular}{|l|c|c|c|}
\hline \multirow{2}{*}{ Sample } & \multicolumn{3}{|c|}{ Protein digestibility, \% } \\
\cline { 2 - 4 } & \multicolumn{1}{|c|}{ Before } & After & $\boldsymbol{p}$ value $^{*}$ \\
\hline Wheat & $50.66 \pm 3.30^{\text {def }}$ & $66.37 \pm 0.14^{\text {bc }}$ & 0.006 \\
\hline Barley & $36.49 \pm 0.97^{\text {de }}$ & $60.59 \pm 1.26^{\mathrm{d}}$ & 0.033 \\
\hline Rye & $53.81 \pm 3.19^{\mathrm{b}}$ & $66.80 \pm 1.02^{\mathrm{bc}}$ & 0.050 \\
\hline Oat & $40.54 \pm 0.10^{\text {cd }}$ & $60.32 \pm 1.30^{\mathrm{d}}$ & 0.042 \\
\hline Paddy & $48.69 \pm 1.24^{\mathrm{bc}}$ & $48.99 \pm 1.76^{\mathrm{e}}$ & 0.893 \\
\hline Bean & $25.98 \pm 0.08^{\mathrm{e}}$ & $60.27 \pm 1.36^{\mathrm{d}}$ & 0.025 \\
\hline Chickpea & $77.29 \pm 2.24^{\mathrm{a}}$ & $78.76 \pm 0.65^{\mathrm{a}}$ & 0.265 \\
\hline Green lentil & $71.60 \pm 2.65^{\mathrm{a}}$ & $72.95 \pm 0.07^{\mathrm{ab}}$ & 0.033 \\
\hline
\end{tabular}


$\mathrm{PD}, \%$, for all grain samples increased after the autoclaving. This increase was statistically significant $(\mathrm{p}<0.05)$ for all grains, except for paddy and chickpeas. A significant increase of the PD values was in barley and beans (Figure 3). The autoclaving process increased PD by $132 \%$ in the bean, but only $2 \%$ increase was observed in the other legume samples. It was reported that autoclaving at $121{ }^{\circ} \mathrm{C}$ reduced the PD in legumes compared to boiling (Rehman and Salariya, 2005). Heat treatments increased the PD of legumes due to the removal of protease inhibitors prevented the absorption of proteins in the intestine, as well as the denaturation of the proteins (Mubarak, 2005). The results achieved in the present study corroborated the finding reported by Messina (2014) showed that heat treatment increased the nutritional bioavailability of beans. The autoclaving has an important effect in terms of MD and $\mathrm{PD}$, especially considering that the legumes are generally cooked under pressure while preparing the foods.

\section{Boiling}

The boiling process significantly decreased $(\mathrm{p}<0.05)$ the PA content in grains, except paddy and chickpeas (Table 4).

Table 4

Phytic acid contents (a) and digestibility rates (b and c) of the of the samples before and after boiling process

(a)

\begin{tabular}{|l|c|c|c|}
\hline \multirow{2}{*}{ Sample } & \multicolumn{3}{|c|}{ Content of Phytic acid, mg/100 g } \\
\cline { 2 - 5 } & Before & After & $\boldsymbol{p}$ value* \\
\hline Wheat & $2471.87 \pm 0.31^{\mathrm{a}}$ & $1200.00 \pm 2.03^{\mathrm{c}}$ & 0.001 \\
\hline Barley & $2328.12 \pm 2.08^{\mathrm{b}}$ & $1231.25 \pm 2.56^{\mathrm{a}}$ & 0.001 \\
\hline Rye & $1715.62 \pm 1.10^{\mathrm{g}}$ & $1046.88 \pm 0.13^{\mathrm{g}}$ & 0.000 \\
\hline Oat & $2050.00 \pm 2.74^{\mathrm{c}}$ & $1109.38 \pm 0.75^{\mathrm{e}}$ & 0.000 \\
\hline Paddy & $1559.37 \pm 0.22^{\mathrm{h}}$ & $1137.50 \pm 0.53^{\mathrm{d}}$ & 0.001 \\
\hline Bean & $1831.25 \pm 1.59^{\mathrm{d}}$ & $1140.63 \pm 0.40^{\mathrm{d}}$ & 0.000 \\
\hline Chickpea & $1806.25 \pm 0.88 \mathrm{e}$ & $1218.75 \pm 2.30^{\mathrm{b}}$ & 0.002 \\
\hline Green lentil & $1790.63 \pm 0.49^{\mathrm{f}}$ & $1100.00 \pm 2.12^{\mathrm{f}}$ & 0.002 \\
\hline
\end{tabular}

(b)

\begin{tabular}{|l|c|c|c|}
\hline \multirow{2}{*}{ Sample } & \multicolumn{3}{|c|}{ Mineral digestibility, \% } \\
\cline { 2 - 4 } & Before & After & $\boldsymbol{p}$ value $^{*}$ \\
\hline Wheat & $45.38 \pm 4.60^{\text {abc }}$ & $57.67 \pm 1.70^{\mathrm{d}}$ & 0.088 \\
\hline Barley & $40.72 \pm 0.00^{\text {bcd }}$ & $64.12 \pm 0.90^{\text {cd }}$ & 0.024 \\
\hline Rye & $45.70 \pm 0.42^{\text {abc }}$ & $57.46 \pm 1.74^{\mathrm{d}}$ & 0.094 \\
\hline Oat & $36.24 \pm 2.01^{\text {cd }}$ & $68.75 \pm 0.57^{\text {bc }}$ & 0.011 \\
\hline Paddy & $30.16 \pm 1.01^{\mathrm{d}}$ & $60.89 \pm 2.33^{\mathrm{d}}$ & 0.048 \\
\hline Bean & $53.83 \pm 1.89^{\mathrm{a}}$ & $75.94 \pm 1.05^{\mathrm{ab}}$ & 0.030 \\
\hline Chickpea & $52.16 \pm 2.74^{\mathrm{ab}}$ & $76.51 \pm 1.11^{\mathrm{a}}$ & 0.029 \\
\hline Green lentil & $52.47 \pm 0.14^{\mathrm{ab}}$ & $75.99 \pm 0.57^{\mathrm{ab}}$ & 0.015 \\
\hline
\end{tabular}


(c)

\begin{tabular}{|l|c|c|c|}
\hline \multirow{2}{*}{ Sample } & \multicolumn{3}{|c|}{ Protein digestibility, \% } \\
\cline { 2 - 4 } & Before & After & $\boldsymbol{p}$ value* \\
\hline Wheat & $50.66 \pm 3.30^{\text {bc }}$ & $55.81 \pm 1.29^{\mathrm{a}}$ & 0.156 \\
\hline Barley & $36.49 \pm 0.97^{\mathrm{de}}$ & $42.72 \pm 1.03^{\mathrm{b}}$ & 0.104 \\
\hline Rye & $53.81 \pm 3.19^{\mathrm{b}}$ & $58.68 \pm 1.17^{\mathrm{a}}$ & 0.150 \\
\hline Oat & $40.54 \pm 0.10^{\mathrm{cd}}$ & $25.52 \pm 1.22^{\mathrm{d}}$ & 0.052 \\
\hline Paddy & $48.69 \pm 1.24^{\mathrm{bc}}$ & $33.83 \pm 2.66^{\mathrm{bcd}}$ & 0.113 \\
\hline Bean & $25.98 \pm 0.08^{\mathrm{e}}$ & $32.55 \pm 2.12^{\mathrm{cd}}$ & 0.199 \\
\hline Chickpea & $77.29 \pm 2.24^{\mathrm{a}}$ & $55.01 \pm 1.20^{\mathrm{a}}$ & 0.034 \\
\hline Green lentil & $71.60 \pm 2.65^{\mathrm{a}}$ & $35.83 \pm 2.10^{\mathrm{bc}}$ & 0.037 \\
\hline
\end{tabular}

* $(P<0.05)$ means that the values statistically different in the same line

**Different letters indicate significant differences $(P<0.05)$ in the same column

The highest PA content was in barley and the lowest one was in the rye. Moreover, it decreased in barley, wheat, and oats by $50 \%$. In a study about the effects of cooking methods on the nutritional quality of some vegetables and legumes, soaking and cooking of the peas and beans were effective in removal or redudictioln of the antinutrients such as PA (Fabbri and Crosby, 2016). In the present study, the boiling process was more effective than the autoclaving in terms of PA degradation (Figure 1). The optimum temperature of the phytase enzyme is 45$60^{\circ} \mathrm{C}$ (Pandey, 2001) and its activity decrease at $60^{\circ} \mathrm{C}$ (Yanke, 1999). Thus, the phytase enzyme degrades at the autoclaving temperature and it was less effective in terms of PA degradation. The boiling chickpeas at $100{ }^{\circ} \mathrm{C}$ for 90 min decreased PA by $28.93 \%$ (Alajaji and El-Adawy, 2006). Singh et al. (2015) found that boiling for $40 \mathrm{~min}$ was effective in reducing the PA. The present case shows that the degradation of PA decreases due to the decrease of phytase enzyme activity if the heat treatment temperature and time applied to the grains increase.

The increase in MD of the grains, except for wheat and rye, was statistically significant $(\mathrm{p}<0.05)$. The boiling process yielded approximately a 2-fold increase in the MD values for the oat and paddy samples. As a result, MD of legume samples was higher than for the cereal grains after the boiling process. PD values decreased in paddy, oat, chickpeas, and green lentils but increased in other samples. However, these changes were statistically non-significant for other cereals, except for the increase in chickpeas and green lentils $(\mathrm{p}>0.05)$.

\section{Effects of fermentation}

The initial level of PA level of cereal flour samples and the levels after the spontaneous fermentation were statistically significantly different $(\mathrm{p}<0.05)$ (Table 5). Since the initial PA conten in rice flour was already lower than that in the other grain flours, the fermentation slightly affected it. PA was at the level of $0.004 \%$ in the endosperm layer of rice (O'Dell et al., 1972). This value is very low when compared to other grains. The fermentation of cereal flours gave high reduction rates in PA (Figure 1). The decrease in PA content was the lowest in rice flour, while the highest decrease in PA content was in barley flour (67\%). Rizzello et al. (2012) reported that the addition of coarse bran to the wheat flour dough increased phytase enzyme activity by 2 times. 
Table 5

Phytic acid contents (a) and digestibility rates (b and c) of the flour samples before and after fermentation process

(a)

\begin{tabular}{|c|c|c|c|}
\hline \multirow{2}{*}{ Sample } & \multicolumn{3}{|c|}{ Phytic acid, mg/100 g } \\
\cline { 2 - 4 } & Before & After & $\boldsymbol{p}$ value $^{*}$ \\
\hline Wheat flour & $1900.00 \pm 0.71^{\mathrm{a}}$ & $662.50 \pm 0.18^{\mathrm{d}}$ & 0.000 \\
\hline Barley flour & $1940.62 \pm 0.66^{\mathrm{b}}$ & $639.06 \pm 1.52^{\mathrm{e}}$ & 0.000 \\
\hline Rye flour & $1709.37 \pm 1.28^{\mathrm{d}}$ & $678.12 \pm 0.09^{\mathrm{c}}$ & 0.000 \\
\hline Oat flour & $1818.75 \pm 0.44^{\mathrm{c}}$ & $714.06 \pm 0.24^{\mathrm{b}}$ & 0.000 \\
\hline Rice flour & $921.87 \pm 0.49^{\mathrm{e}}$ & $718.75 \pm 0.75^{\mathrm{a}}$ & 0.002 \\
\hline
\end{tabular}

(b)

\begin{tabular}{|c|c|c|c|}
\hline \multirow{2}{*}{ Sample } & \multicolumn{3}{|c|}{ Mineral digestibility, \% } \\
\cline { 2 - 4 } & Before & After & $\boldsymbol{p}$ value* \\
\hline Wheat flour & $49.61 \pm 0.49^{\mathrm{a}}$ & $80.50 \pm 1.22^{\mathrm{a}}$ & 0.025 \\
\hline Barley flour & $44.61 \pm 0.60^{\mathrm{a}}$ & $82.53 \pm 1.23^{\mathrm{a}}$ & 0.021 \\
\hline Rye flour & $58.30 \pm 1.20^{\mathrm{a}}$ & $84.37 \pm 1.67^{\mathrm{a}}$ & 0.041 \\
\hline Oat flour & $46.44 \pm 6.08^{\mathrm{a}}$ & $81.71 \pm 0.12^{\mathrm{a}}$ & 0.002 \\
\hline Rice flour & $58.35 \pm 2.86^{\mathrm{a}}$ & $83.98 \pm 1.91^{\mathrm{a}}$ & 0.047 \\
\hline
\end{tabular}

(c)

\begin{tabular}{|c|c|c|c|}
\hline \multirow{2}{*}{ Sample } & \multicolumn{3}{|c|}{ Protein digestibility, \% } \\
\cline { 2 - 4 } & Before & After & p value* \\
\hline Wheat flour & $74.46 \pm 2.19^{\mathrm{a}}$ & $80.22 \pm 0.37^{\mathrm{a}}$ & 0.041 \\
\hline Barley flour & $65.19 \pm 2.85^{\mathrm{a}}$ & $70.51 \pm 0.14^{\mathrm{d}}$ & 0.017 \\
\hline Rye flour & $66.51 \pm 1.09^{\mathrm{a}}$ & $74.13 \pm 0.46^{\mathrm{c}}$ & 0.038 \\
\hline Oat flour & $65.63 \pm 1.41^{\mathrm{a}}$ & $74.64 \pm 0.44^{\mathrm{c}}$ & 0.031 \\
\hline Rice flour & $66.13 \pm 0.43^{\mathrm{a}}$ & $77.39 \pm 0.32^{\mathrm{b}}$ & 0.018 \\
\hline
\end{tabular}

* $(P<0.05)$ means that the values statistically different

$* *$ Different letters indicate significant differences $(P<0.05)$ in the same column

This shows that cereal bran has a high phytase activity. In the present study, rice flour, which had lower phytase activity since it does not contain bran layer, presented less PA decrease by the fermentation. The phytase enzyme has broad substrate specificity and usually exhibits optimum activity in the range between $\mathrm{pH} 4.5$ and 6.0 (Pandey et al., 2001). Leenhardt et al. (2005) showed that, due to the acidity formed by lactic acid bacteria in sourdough 
fermentation, the $\mathrm{pH}$ dropped below 5.5 and the increased phytase activity decreased the PA content in wheat flour by $70 \%$. In the present study, $\mathrm{pH}$ values were determined to be 4.5 in wheat flour, 4.6 in oat flour, 4.7 in rye flour, 4.6 in barley flour, and 4.1 in rice flour after the fermentation. Thus, the post-fermentation $\mathrm{pH}$ values of cereal flours reached an adequate acidity level of $\mathrm{pH}$ 4.0-6.0, where the phytase enzyme could show optimum activity and PA degradation occurred.

The difference between initial MD values of cereal flours was statistically non-significant $(p>0.05)$. It was determined that there was a significant $(p<0.05)$ increase in MD after spontaneous fermentation for all flour samples. Because of fermentation of the barley flour having the lowest MD, its digestibility increased by approximately by 2 times.

The differences between the initial PD values of flour samples were statistically nonsignificant. Increases in PD after fermentation were, however, statistically significant $(\mathrm{p}<0.05)$. It is known that the lactic acid bacteria had also protease activity, and they activated the endogenous enzymes naturally found in the cereals through the organic acids, which are important metabolites produced during fermentation. Because of both direct and indirect protease activities in the dough, content of proteins decreased and water-soluble nitrogenous substances and PD increased (Gobbetti et al., 2014). Furthermore, it was indicated that the free amino acid levels in the medium increased as a result of the breakdown of proteins (Hansen and Schieberle, 2005).

\section{Conclusion}

Examining all the processes applied in the present study together, it can be said that germination and fermentation processes are the most effective methods. In general, all the processes reduced the amount of phytic acid, which is an important antinutrient. Some of these methods are already used in the preparation of cereals and legumes as food. Therefore, soaking of chickpeas and beans, boiling them in water, and then cooking not only softens the grain but also reduces the level of phytic acid and increases mineral and protein digestibilities. The combination of heating, fermentation, autoclaving, and other processes used in the present study, which affect via the change of chemical structure, the formation of insoluble complexes, and degradation of phytic acid can be suggested as a treatment that resulted in the significant reduction of the content of $\mathrm{PA}$.

\footnotetext{
Acknowledgements. The authors would like to thank Kastamonu University Scientific Research Projects Coordination Unit (KUBAP) for their financial support to this research (Project No: KUBAP-01/2017-56).
}

\section{References}

AACC (2000), Approved methods of the American Association of Cereal Chemists, Tenth ed. St. Paul.

Abdelrahaman S.M., El Maki H.B., Babiker E.E., El Tinay A.H. (2005), Effect of malt pretreatment followed by fermentation on antinutritional factors and HCl- Extractabil-ity of minerals of pearl millet cultivars, J. Food. Technol., 3, pp. 529-534.

Adil Shah S., Zeb, A., Masood T., Noreen N., Abbas S.J., Samiullah M., et al. (2011), Effects of sprouting time on biochemical and nutritional qualities of mung bean varieties, Afr. J. Agric. Res. 6(22), pp. 5091-5098. 


\section{- Food Technology -}

Alajaji S.A., El-Adawy T.A. (2006), Nutritional composition of chickpea (Cicer arietinum L.) as affected by microwave cooking and other traditional cooking methods, J. Food Compost. Anal. 19(8), pp. 806-812, DOI: 10.1016/j.jfca.2006.03.015

Bottega G., Caramanico R., Lucisano M., Mariotti M., Franzetti L., Pagani, M.A. (2009), The debranning of common wheat (Triticum aestivum L.) with innovative abrasive rolls, J. Food Eng., 94, pp. 75-82, DOI: 10.1016/j.jfoodeng.2009.03.002

Coulibaly A., Kouakou B., Chen J. (2011), Phytic acid in cereal grains: healthy or harmful ways to reduce phytic acid in cereal grains and their effects on nutritional quality Amer. J. Plant. Nutr. Fertil. Tech., 1, pp. 1-22, DOI: 10.3923/ajpnft.2011.1.22

Oomah B.D., Francois C., Linda J.M., Anne-Sophie B. (2011), Phenolics and antioxidant activity of lentil and pea hulls, Food Res. Int., 44, pp. 436-441, DOI: 10.1016/j.foodres.2010.09.027

Deng Y., Padilla-Zakour O., Zhao Y., Tao S. (2015), Influences of high hydrostatic pressure, microwave heating, and boiling on chemical compositions, antinutritional factors, fatty acids, invitro protein digestibility, and microstructure of buckwheat, Food Bioproc. Tech., 8, pp. 2235224, DOI: 10.1007/s11947-015-1578-9

El-Adawy T.A., Rahma E.H., El-Bedawey A.A., El-Beltagy A.E. (2003), Nutritional potential and functional properties of germinated mung bean, pea and lentil seeds, Plant. Foods. Hum. Nutr., 58, pp. 1-13, DOI: 10.1023/B:QUAL.0000040339.48521.75

Eltayeb M.M., Hassn A.B., Sulieman M.A., Babiker E.E. (2007), Effect of processing followed by fermentation on antinutritional factors content of pearl millet (Pennisetum glaucum L.) cultivars, Pak. J. Nutr., 6(5), pp. 463-467, DOI: 10.3923/pjn.2007.463.467

Ergün A., Tuncer Ş.D., Çolpan İ., Yalçın S., Yıldız G., Küçükersan M.K. et al. (2002), Yemler, Yem Hijyeni ve Teknolojisi. Ankara Üniversitesi Veteriner Fakültesi, Hayvan Besleme ve Beslenme Hastalıkları Anabilim Dalı, Ankara, p. 465.

Ertop M.H., Bektaş, M. (2018), Enhancement of bioavailable micronutrients and reduction of antinutrients in foods with some processes, J. Food. Health. Sci., 4(3), pp. 159-165, DOI: 10.3153/FH18016

Fabbri A.D.T., Crosby G.A. (2016), A review of the impact of preparation and cooking on the nutritional quality of vegetables and legumes, Int. J. Gastron. Food. Sci., 3, pp. 2-11, DOI: 10.1016/j.ijgfs.2015.11.001

Fayyaz N., Mohebbi M., Milani E. (2018), Effect of germination on nutrients, mineral, phytic acid and enzyme activity of mung bean, Acta. Medica. Mediterr., 34, pp. 597-605, DOI: 10.19193/0393-6384_2018_2s_94

Ghavidel R.A., Prakash J. (2007), The impact of germination and dehulling on nutrients, antinutrients, in-vitro iron and calcium bioavailability and in-vitro starch and protein digestibility of some legume seeds, LWT - Food Sci.\& Technol., 40, pp. 1292-1299, DOI: 10.1016/j.lwt.2006.08.002

Gibson R.S., Bailey K.B., Gibbs M., Ferguson E.L. (2010), A review of phytate, iron, zinc, and calcium concentrations in plant-based complementary foods used in low-income countries and implications for bioavailability, Food Nutr. Bull., 31(2), pp. 134-146, http://dx.doiorg/10.1177/15648265100312S206

Gobbetti M., Rizzello C.G., Cagno R.D., Angelis M.D.(2014), How the sourdough may affect the functional features of leavened baked goods, Food Microbiol., 37, pp. 30-40, DOI: 10.1016/j.fm.2013.04.012

Greiner R., Konietzny U. (2006), Phytase for food application, Food Technol. Biotechnol., 44, pp. 125-140, DOI: 10.1016/j.fm.2013.04.012

Gupta R.K., Gangoliya S.S., Singh N.K. (2015), Reduction of phytic acid and enhancement of bioavailable micro-nutrients in food grains. J. Food. Sci. Technol., 52(2), pp. 676-684, DOI: 10.1007/s13197-013-0978-y 
Hansen A., Schieberle P. (2005), Generation of aroma compounds during sourdough fermentation: applied and fundamental aspects, Trends Food Sci. Technol., 16, pp. 85-94, DOI: 10.1016/j.tifs.2004.03.007

Haug W., Lantzsch, H.J. (1983), Sensitive method for the rapid determination of phytic acid incereals and cereal products, J. Sci. Food. Agric., 34, pp. 1423-1426, DOI: 10.1002/jsfa.2740341217

Hayta M., Hendek Ertop, M. (2017), Optimization of sourdough bread incorporation into wheat bread by response surface methodology: bioactive and nutritional properties. Int. J. Food. Sci. Technol., 52(8), pp. 1828-1835, DOI: 10.1111/ijfs.13457

Khalil A.H., Mansour E.H. (1995), The effect of cooking, autoclaving and germination on the nutritional quality of faba beans, Food Chem., 54, pp. 177-182, DOI: 10.1016/03088146(95)00024-D

Leenhardt F., Levrat-Verny M.A., Chanliaud E., Remesy C.(2005), Moderate decrease of pH by sourdough fermentation is sufficientto reduce phytate content of whole wheat flour through endogenous phytase activity, J. Agric. Food Chem., 53, pp. 98102.https://doi.org/10.1021/jf049193q.

Lestienne I., Caporiccio B., Besancon P., Rochette I., Treche S. (2005), Relative contribution of phytates, fibers and tannins to low iron and zinc invitro solubility in pearl millet (Pennisetum glaucum) flour and grain fractions, J. Agric. Food Chem., 53, pp. 8342-8348, DOI: 10.1021/jf050741p

Ma D., Zuo Y., Sun D., Wang C., Guo T.(2013), Characterization of the TaMIPS gene from winter wheat (Triticum aestivum L.) and changes in its expression pattern with phytic acid accumulation in seeds during grain filling, J. Cereal Sci., 57(3), pp. 437-443, DOI: 10.1016/j.jcs.2013.01.012

Marshall A.A., Samuel J.E., Mary U.E., Inegbenose G.I. (2011), Effect of germination on the phytase activity, phytate and total phosphorus contents of rice, maize, millet, sorghum and wheat, J. Food Sci. Technol., 48, pp. 724-729, DOI: 10.1007/s13197-010-0186-y

Masud T., Mahmood T., Latif A., Sammi S., Hameed T.(2007), Influence of processing and cooking methodologies for reduction of phytic acid content in wheat (Triticum aestivum) varieties, J. Food Process. Preserv, 31, pp. 583-594, DOI: 10.1111/j.1745-4549.2007.00147.x

Messina V. (2014), Nutritional and health benefits of dried beans, Am. J. Clin. Nutr., 100, pp. 437-442, DOI: 10.3945/ajcn.113.071472

Mubarak A., (2005), Nutritional composition and antinutritional factors of mung bean seeds (Phaseolus aureus) as affected by some home traditional processes, Food Chem., 89, pp. 489495, DOI: 10.1016/j.foodchem.2004.01.007

O'Dell B.L., De Boland A.R., Koirtyohann S.R.(1972), Distribution of phytate and nutritionally important element among the morphological of cereal grains, J. Agric. Food Chem., 20, pp. 718.

Özkaya B., Turksoy S., Özkaya H., Duman B. (2017a), Dephytinization of wheat and rice brans by hydrothermal autoclaving process and the evaluation of consequences for dietary fiber content, antioxidant activity and phenolics, Innov. Food Sci. Emerg. Technol., 39, pp. 209-215. DOI: 10.1016/j.foodchem.2004.01.007

Özkaya B., Turksoy S., Özkaya H., Baumgartner B., Özkeser İ., Köksel H. (2018), Changes in the functional constituents and phytic acid contents of firiks produced from wheats at different maturation stages, Food Chem., 246, pp. 50-155, DOI: 10.1016/j.foodchem.2017.11.022

Özkaya H., Özkay B., Duman B., Turksoy S. (2017b), Effect of dephytinization by fermentation and hydrothermal autoclaving treatments on the antioxidant activity, dietary fiber, and phenolic content of oat bran, J. Agric. Food Chem., 65, pp. 5713-5719, DOI: 10.1021/acs.jafc. $7 \mathrm{~b} 01698$ 
Pakfetrat S., Amiri S., Radi M., Abedi E.(2018), Reduction of phytic acid, aflatoxins and other mycotoxins in wheat during germination, J. Sci. Food. Agric., 99, pp. 4695-4701, DOI: $10.1002 /$ jsfa.9710

Pandey A., Szakacs G., Soccol C.R., Rodriguez-Leon J.A., Soccol V.T. (2001), Production, purification and properties of microbial phytases, Bioresour. Technol., 7, pp. 203-214. DOI: 10.1016/S0960-8524(00)00139-5

Perera I., Seneweera S., Hirotsu N. (2018), Manipulating the phytic acid content of rice grain toward improving micronutrient bioavailability, Rice., 11, 4. DOI: 10.1186/s12284-018-0200-y

Perlas L., Gibson, R.S. (2002), Use of soaking to enhance the bioavailability of iron and zinc from rice-based complementary foods used in the Philippines, J. Sci. Food. Agric., 82, pp. 11151121, DOI: $10.1002 /$ jsfa. 1156

Peterson D.M. (1998), Malting oats: Effects on chemical composition of hull-less and hulled genotypes, Cereal Chem., 75, pp. 230-234, DOI: 10.1094/CCHEM.1998.75.2.230

Rehman Z., Salariya A.M. (2005), The effects of hydrothermal processing on antinutrients, protein and starch digestibility of food legumes, Int. J. Food. Sci. Technol., 40, pp. 695-700, DOI: 10.1111/j.1365-2621.2005.00978.x

Rizzello C.G., Coda R., Mazzacane F., Minervini D., Gobbetti M. (2012), Micronized byproducts from debranned durum wheat and sourdough fermentation enhanced the nutritional. Textural and Sensory Features of Bread. Food Res. Int., 46, pp. 304-313, DOI: 10.1016/j.foodres.2011.12.024

Rizzello C.G., Curiel J.A., Nionelli L., Vincentini O., Cagno R.D., Silano, M., et al. (2014), Use of fungal proteases and selected sourdough lactic acid bacteria for making wheat bread with an intermediate content of gluten, Food Microbiol., 37, pp. 59-68, DOI: 10.1016/j.fm.2013.06.017

Sharif M., Hussain A., Subhani M. (2013), Use of sprouted grains in the diets of poultry and ruminants, Paripex Indian. J. Res., 10(2), pp. 1-7.

Singh P.K., Shrivastava N., Sharma B., Bhagyawant S.S. (2015), Effect of domestic processes on chickpea seeds for antinutritional contents and their divergence, Amer. J. Food Sci. Technol., 3(4), pp. 111-117, DOI: 10.12691/ajfst-3-4-3

Skoglund M., Peterson D.M., Andersson R., Nilsson J., Dimberg L.H. (2008), Avenanthramide content and related enzyme activities in oats as affected by steeping and germination, J. Cereal Sci., 48, pp. 294-303, DOI: 10.1016/j.jcs.2007.09.010

Vats P., Banerjee U.C. (2004), Production studies and cat-alytic properties of phytases (myoinositol-hexakis-phos-phate phosphohydrolases): an overview, Enzyme Microb. Technol., 35, pp. 3-14, DOI: 10.1016/j.enzmictec.2004.03.010

Wang R., Guo S. (2021), Phytic acid and its interactions: Contributions to protein functionality, food processing, and safety. Compr. Rev. Food Sci. Food Saf., 20(2), pp. 20812105. DOI: $10.1111 / 1541-4337.12714$

Yagoub A., Mohammed A., Abu Baker, A. (2008), Effect of soaking, sprouting and cooking on chemical composition, bioavailability of minerals and in-vitro protein digestibility of roselle (Hibiscus sabdariffa L.) seed, Pak. J. Nutr., 7(1), pp. 50-56, DOI: 10.3923/pjn.2008.50.56

Yanke L.J., Selinger L.B., Cheng K.J. (1999), Phytase activity of Selenomonas ruminantium: a preliminary characterization, Lett. Appl. Microbiol., 29, pp. 20-25, DOI: 10.1046/j.13652672.1999.00568.x 